\title{
Lusioersily
}

\section{Mobilizing capacity to achieve the mainstreaming of disability sport}

Kitchin, P. J., Peile, C., \& Lowther, J. (2019). Mobilizing capacity to achieve the mainstreaming of disability sport. Managing Sport and Leisure, 24(6), 424-444. [6]. https://doi.org/10.1080/23750472.2019.1684839

Link to publication record in Ulster University Research Portal

\section{Published in:}

Managing Sport and Leisure

Publication Status:

Published online: 01/11/2019

DOI:

$10.1080 / 23750472.2019 .1684839$

\section{Document Version}

Author Accepted version

\section{General rights}

Copyright for the publications made accessible via Ulster University's Research Portal is retained by the author(s) and / or other copyright owners and it is a condition of accessing these publications that users recognise and abide by the legal requirements associated with these rights.

\section{Take down policy}

The Research Portal is Ulster University's institutional repository that provides access to Ulster's research outputs. Every effort has been made to ensure that content in the Research Portal does not infringe any person's rights, or applicable UK laws. If you discover content in the Research Portal that you believe breaches copyright or violates any law, please contact pure-support@ulster.ac.uk. 
Mobilizing capacity to achieve the mainstreaming of disability sportP. J. Kitchin*

Ulster University

Charlotte Peile

Ulster University Students' Union

Jim Lowther

Ulster University

*Corresponding author, via

pj.kitchin@ulster.ac.uk

School of Sport, Ulster University, Jordanstown, Newtownabbey, Co. Antrim, Northern Ireland, BT370QB 


\section{Mobilizing capacity to achieve the mainstreaming of disability sport}

Rationale: Mainstreaming is the policy of integrating the responsibility for disability sport provision into nondisabled sports organizations. While a contemporary organizational practice, we know little about how this process works.

Purpose: We explore how sports organizations mobilized organizational capacity to implement mainstreaming.

Method: Multiple case analyses was constructed on the experiences of three non-profit, provincial Northern Irish sporting organizations through documents and interviews.

Findings: In order to mainstream disability sport financial, human, and network resources were combined and leveraged. Specifically, funds underpinned a commitment from staff, who drew upon their networks to attract and retain volunteers, educate the workforce, and develop more networks essential for programme creation. In each case however, insufficient planning limited the type and diversity of inclusive provision, and threatened sustainability.

Practical Implications: Strategies need to be led by a community of practice drawn from the mixed economy of providers that support the development of disabled people through sport, not just sport organisations themselves.

Research Contribution: This study provides new insights into how capacity is mobilized to mainstream disability sport. It highlights that appropriate policy support and planning mechanisms need to be in place before provision is enacted to ensure more inclusive provision from the outset.

Keywords: Mainstreaming, integration, organizational capacity, disability sport, inclusion 


\section{Mobilizing capacity to achieve the mainstreaming of disability sport}

\section{Policy implementation issues in disability sport}

The success, or otherwise of policy implementation in grassroots sport is well documented in the sport policy and sport management literatures (Adams, 2014; Harris \& Houlihan, 2015, 2016; Jeanes, Spaaij, Magee, Farquharson, Gorman \& Lusher, 2018; Mackintosh, Darko, Rutherford \& Wilkins 2015; Skille, 2008; Spaaij, Farquharson, Magee, Jeanes, Lusher \& Gorman, 2014; Stenling, 2013). Policy implementation involves government goals being operationalized by sports organizations. In the context of the current study, the policy to increase the participation of people with disabilities in sport in Northern Ireland has seen a significant increase in funding invested (Sport NI, 2012). However, policy intent can be muddied during implementation (Adams, 2014), particularly policy directives aimed at social inclusion through sport (Haudenhuyse, 2017; Jeanes et al., 2018) when these conflict with business and/or sporting mandates (Spaaij et al., 2014; Stenling, 2013). Research into policy implementation in disability sport is nascent (Jeans, et al. 2018; Kitchin \& Howe, 2014; Sørensen \& Khars, 2006) but what has been found is a complex set of structural barriers make implementation challenging.

In Europe alone, there are 80 million individuals with a disability and with a gradually ageing population, these numbers are set to increase (LeClair, 2011; Paramio-Salcines, Grady \& Downs, 2014). Often progress in developing sports for individuals with a disability are beset with barriers that limit or impede their participation. Many of these barriers exist on the demand-side of participation, meaning they occur because of an individual's personal circumstances - which can include insufficient financial resources (Crawford \& Stodolska, 2009), time (Sotiriadou \& Wicker, 2014), friends (Darcy, Lock \& Taylor, 2017), awareness of programmes (Collins \& Kay, 2003), and when these are combined with individual's type 
of disability (Darcy, et al., 2017; Sotiriadou \& Wicker, 2014) myriad constraints are experienced. On the supply-side of sport, certain practices and procedures create additional barriers that limit participation. These include inaccessible facilities (Crawford \& Stodolska, 2009; French \& Hainsworth, 2001; Paramio-Salcines \& Kitchin, 2013), inaccessible transport (Crawford \& Stodolska, 2009; French \& Hainsworth, 2001), unsuitable programmes (Jones, 2003), inadequate planning (Wicker \& Breuer, 2014), insufficient support (Darcy, et al., 2017), and outdated social perceptions held by both staff (Fitzgerald, 2012; French \& Hainsworth, 2001; Hammond, Penney \& Jeans, 2019; Jones, 2003; Sørensen \& Khars, 2006) and wider stakeholders (Brittain, 2004).

Much policy attention to address these issues has focused on merging disability sport organizations and their participants into nondisabled sporting organizations (Howe, 2007; Hammond, 2019; Hums, Moorman \& Wolff, 2003; Kitchin \& Howe, 2014; Sørensen \& Khars, 2006) through a process termed vertical integration, or mainstreaming (Thomas \& Smith, 2009). Mainstreaming has been defined as "integrating the delivery and organization of [formalized] sporting opportunities to ensure a more coordinated and inclusive sporting system” (Kitchin \& Howe, 2014, p. 66).

Mainstreaming aims to include people with disabilities in all aspects of their governance and operations. To create accessible and inclusive spaces, people with disabilities need to be offered a choice of participation options (Darcy, et al., 2017; Misener \& Darcy, 2014). Inclusive practice should be operationalized through the inclusion spectrum; which offers a range of possible sport and leisure activities (Misener \& Darcy, 2014; Stevenson, 2009). Misener \& Darcy (2014, p. 4) state that "inclusion from [a choice] perspective is about accepting responsibility for the provision of sporting opportunities and taking the necessary steps to ensure that everyone is given equal chance to participate". This choice is often down to an organization's capacity to deliver. 
Currently, many government services are delivered by charities, social enterprises and co-operatives, sport being no exception (Dey \& Teasdale, 2016). To understand how a nonprofit fulfils their mission, increasing attention is needed to understand how capacity can be mobilized and enhanced. Following Eisenger (2002, p. 117), the term capacity is "a set of attributes that any particular organization possess constitute the organization's capacity profile". These attributes have been theorized into multidimensional frameworks which specify dimensions of organizational resources; human, financial, procedural and networks that are crucial to mission success (Eisinger, 2002; Germann \& Wilson, 2004; Hall et al., 2003).

It is how these aspects of organizational capacity are mobilized that is of interest in this study. As such, this paper examines how capacity was mobilized by three PSOs in response to public sector funding (2013-2015) designed to boost the sport participation of people with disabilities. They did so by targeting the three largest PSOs in the region, Ulster Rugby, The Irish Football Association (IFA) and the Ulster Gaelic Athletic Association (GAA). Each organization is culturally significant in Northern Irish sport (Liston, Gregg, \& Lowther, 2012; Sugden, 1991). We use a multiple-case study approach (Stake, 2006; Yin, 2018) to gather data on this process which will make a novel contribution to the mainstreaming disability sport literature. Findings from the three cases suggest that finance, human resources and networks are significant determinants of programme expansion, yet insufficient planning can limit the potential for sufficient capacity building that could sustainably mainstream disability sport.

\section{Contextual background}


Northern Ireland (NI) is a country of the United Kingdom with a population of 1.81 million (Northern Ireland Statistics and Research Agency - NISRA, 2017). Northern Ireland has three key pieces of legislation governing disability; The Disability Discrimination (Northern Ireland) Order (DDO) 2006, the Autism Act (2011) and Section 75 of NI Act 1998. These articles ensure that an individual cannot be discriminated against based on a longstanding illness or disability. However, the participation of people with disabilities in Northern Irish society is lower than the non-disabled population. NISRA (2017) documented that $19.8 \%$ of the population reported that their day-to-day activities were limited because of a long-standing health problem or disability. Two households in every five have at least one individual with a long-standing health problem or disability, with urban and town areas reporting higher figures.

Sport in this region is led a combination of public sector and non-profit organisations. The Stormont Executive is responsible for governing the region and within its departments, sport falls under the remit of the Department of Communities. Sport Northern Ireland (Sport NI) is the Sport Council and the 'quango' responsible for implementing the region's sport strategy (Sport Matters: Sport NI, 2009). Provincial Sports Organizations (PSOs) are nonprofit sports governing bodies that operate at a level akin to State Sporting Associations in countries like Canada or Australia. Many PSOs are core-funded by Sport NI to provide sporting opportunities across a unique region, which either includes the 6 British counties of Northern Ireland or the 9 Irish counties of Ulster. Disability Sport Northern Ireland (DSNI) is the lead agency responsible for training, information, advice and support to sports organizations whilst offering a range of programmes. The non-profit DSNI works in collaboration with the public sector, Sport NI, the PSOs and a mixed economy of smaller providers to support the development of elite and grassroots disability sport. 
Specific policies and strategic documents regarding the development and the management of disability sport are few. The only specific disability sport policy at the time of this study was the Disability Mainstreaming Policy (DMP) launched in 2006. This sport sector-specific policy encouraged both Sport NI and the PSOs to adopt five conditions, (1) promote disability sport; (2) provide equitable access to participation opportunities for people with disabilities; (3) offer full consultation in future sport policy; (4) develop programme and policies that are targeted to specific needs; (5) take positive actions to redress the historical marginalization of persons with a disability (Sport NI, 2011). Since its publication there has been no strategy provided to suggest possible policy implementation, as such ideas on the specifics on how to achieve the remit lay at the discretion of each individual PSO.

Despite this lack of strategy, since the publication of the DMP investment in disability sport has increased by nearly 45\% between 2006 and 2012 (Sport NI, 2012). Sport NI claims this has resulted in increased opportunities, although they temper this with the admission that the most notable advances are in the areas of elite performance (Sport NI, 2013). This remains a concern as the Sport and Physical Activity Survey (Sport NI, 2012) found that people with disabilities in Northern Ireland experience lower participation rates and experience lower quality of service in every KPI in the national strategy (please see table 1). Therefore, the need to boost grassroots disability sport participation in the region is dire but given the diversity f providers within the mixed economy coordination of efforts is a challenging task.

\section{Please insert table 1 about here}




\section{Literature review}

\section{Organizational capacity in non-profit sport}

In the non-profit sport context, organizational capacity has been examined through two approaches. The first approach has sought to identify and determine the various organizational capacity dimensions and their relationship to an organization's ability to achieve its mission (Balduck, Lucidarme, Marlier \& Willem, 2015; Wicker \& Breuer, 2012). The second, has examined how organizations go about generating or building elements of capacity to address gaps in these dimensions (Casey, Payne \& Eime, 2009a; Millar \& Doherty, 2018). Both of these relevant areas are introduced forthwith.

\section{Dimensions of capacity in non-profit sport}

Understanding the role of capacity in nonprofit sport has been examined extensively through the application Hall et al.'s (2003) capacity dimensions; human, financial and structural. Each of the three dimensions has at various times been found to be central to success, with human resources capacity having been reported consistently imperative (Balduck, et al., 2015; Misener \& Doherty, 2009; Svensson \& Hambrick, 2018; Svensson, Hancock \& Hums, 2017; Swierzy, Wicker \& Breuer, 2018; Wicker \& Breuer, 2012, 2014). The prevalence, and effective use, of financial capacity underpins mission achievement as it can assist in determining the volumes of capacity dimensions (Svensson et al., 2017; Svensson, Andersson \& Faulk, 2018; Swierzy et al., 2018; Wicker \& Breuer, 2014).

Research has found that in a variety of nonprofit sport contexts, structural capacity's sub-dimensions are also linked to success. This is true for relationship and network capacity (Jones, Edwards, Bocarro, Bunds \& Smith, 2017, 2018; Misener \& Doherty, 2009; Misener \& Doherty, 2013; Svensson et al., 2018), planning and development capacity (Wicker \& Breuer, 2012, 2014), and infrastructure and process capacity (Balduck, et al., 2015; Misener 
\& Doherty, 2009; Svensson et al., 2017). Within the specific context of disability sport Wicker \& Breuer (2014) revealed that larger multi-sport clubs were more likely to provide disability sport when they had sufficient financial capacity, well developed networks and adopted formal and strategic planning processes.

\section{Building capacity in non-profit sport}

In addition to the research examining which dimensions determine organizational success, another vein of literature has investigated how capacity is developed to overcome organizational weaknesses. In the sport literature, this has included studying how planning (Thomas, Hodge \& Smith, 2009) and monitoring and evaluation (Harris, 2018) can be developed to address deficiencies. To understand how capacity is built, frameworks have been used to explore the determinants of successful capacity building outcomes (Casey, Payne \& Eime, 2009b, 2012; Rosso \& McGrath, 2017). Casey et al., (2012) found that effective capacity building was linked to an organization's readiness to adapt to new situation, which was also affected by the availability of their financial resources. In addition to the availability of finance, the development of networks and relationships were vital. Marlier, Lucidarme, Cardon, De Bourdeaudhuij, Babiak and Willem (2015) examined how certain aspects of cross-sector partnerships, such as trust and mutuality were strong determinants of effective working. Combining Hall et al.'s (2003) framework with Berry's (1996) theory of acculturation, Kitchin and Crossin (2018) explored the efforts of disability football clubs to build integrative capacity - the capacity to facilitate mainstreaming. They found that these clubs could form partnerships with high profile nondisabled football clubs to increase their chances of survival. These partnerships permitted disability football clubs to leverage the parent club's brand, thus generating sufficient human and financial resources for sustainability. 
Despite a growing interest in capacity building, conceptual ambiguity complicates the comparability of capacity-building research (Griginov, Peshin \& Belousov, 2017; Millar \& Doherty, 2016). Charting a direction out of this mire, Millar and Doherty (2016) proposed a capacity-building process-model that sought to address capacity building in its wider, organizational context. Their model included an understanding of the stimulus for, needs assessment of and organizational readiness for capacity building. In implementing this framework, they stress that most research in the area of capacity building, seeks to understand how sport can be used as the tool to develop individuals or communities. Because of this insufficient focus on impacts at the organizational level (Millar and Doherty, 2018). We are cognizant of their recommendation to focus the unit of analysis at the organizational level, and as such this is where this current study is situated. Indeed, our focus is on how sport organizations mobilize capacity in direct response to being awarded funds to implement a policy. By doing so we seek to contribute a further application of how capacity is linked to policy implementation within the specific context of mainstreaming disability sport.

\section{Research Design}

An interpretive case study was chosen as the research design for this project. Interpretivist ontologies posit that reality is socially constructed, subjective, and changeable. The choice of an interpretivist epistemology was chosen because knowledge is based on the subjective meanings of individuals on social phenomena which can have multiple interpretations - such mainstreaming disability sport (Wahyuni, 2012). To permit greater understanding about capacity, renewed calls have been made for more case studies on the non-profit sport organizations (Balduck et al., 2015; Misener \& Doherty, 2009; Sharpe, 2006). Hence to capture the contextually specific elements of mainstreaming in Northern Irish sport we adopt a multiple case study structure whereby we pose the following research question; how do 
provincial sports organizations mobilize the capacity to mainstream disability sport? To address this, we decided upon a multiple case study approach for exploring relevant phenomena (Stake, 2006; Yin, 2018). This approach has proven useful for exploring the capacity building process and outlining differences between cases (Millar \& Doherty, 2018) and it suited our interpretive approach.

\section{Cases}

Purposive, non-probability sampling procedures were used to determine the cases, documents, and respondents. First, to determine the sample of cases we chose purposive sampling criteria by drawing on news reports and word of mouth accounts of the PSOs funded to mainstream disability sport (Millar \& Doherty, 2018; Thomson, Darcy \& Pearce, 2010). Three organizations were selected, and queries were made through the sport development departments of each PSO for staff responsible for programme design, implementation, and evaluation. Following the suggestions of Millar and Doherty (2018), these cases were bounded by focusing our unit of analysis at the organisational level and seeing how capacity was mobilized within each case to boost the sport participation of people with disabilities. All activities that pertained to the pre-existing, and emergent grassroots programming relevant to this area, including organisational strategies and plans of each PSO were deemed relevant. Data relevant to elite sport development that fell outside the remit of the 3-year government funding grant was excluded.

Three organizations were selected as cases for this research on the basis that they a) were funded, b) were the largest sporting organizations in the region and c), were representative of the various communities of the region. This size is confirmed by Deloitte (2014) which identified that each PSO had over 50,000 regular participants and many more volunteers (further details on each case is below and in Table 2). 


\section{Please insert table 2 about here}

The organization in case study 1 is the Irish Football (Soccer) Association (IFA). Established in 1880 the IFA is now the National Governing Body for the sport of Association Football in the 6 counties of Northern Ireland. Within Northern Ireland there are over 1000 football clubs with approximately 25,000 participants. The IFA is responsible for the development and implementation of their strategy (IFA, 2013) within Northern Ireland. The IFA's annual operating budget is approximately GBP£11m per annum that funds grassroots and elite national teams' football and the development of the human and physical infrastructure for the sport. Based at the National Stadium in Belfast, the IFA employs over 100 staff and has a network of volunteers across the nation.

Case study 2 is on the Irish Rugby Football Union (Ulster Branch), who is responsible for the development of rugby in the 9-county province of Ulster. Within this region over 35,000 people are registered players within 53 clubs that boast 141 adult men's teams, and 20 women's teams, plus 98 school and youth teams. The PSO reports to the IRFU, based in Dublin, Ireland and operates as both a professional sporting club (called Ulster Rugby) and a sports development organization (called Ulster Branch). The IRFU sets the national strategy (IRFU, 2013), of which the Ulster Branch is responsible for implementation within the province. To assist this, the Ulster Branch receives approximately GBP£20m per annum from the IRFU to assist in funding their operations. Their head office is located at their stadium in Belfast and at the time of the case study they employed approximately 60 staff.

Our third case study is on the Ulster Gaelic Athletic Association (Ulster GAA) who act as Provincial Council and governing body for the GAA within the 9 counties of Ulster. There are approximately 580 clubs, with over 250,000 members, 100,000 of these active participants. The Ulster GAA set and implement their own strategy within the region (Ulster GAA, 2009). The Ulster GAA’s annual operating income is approximately $£ 5 \mathrm{~m}$ per annum 
and directly funds the sports of hurling, Gaelic football, and supports the sports of camogie, handball and rounders with funding while also promoting Irish culture and language (Ulster GAA 2011; 2012). Roughly 50\% of the branch's income arrives through Gate Receipts and Grant Income (Ulster GAA, 2009). Based in Armagh, the Ulster GAA employs over 60 staff and is estimated to train and develop over 1000 volunteers each year.

\section{Data collection}

Following direction from Prior (2003), we created document selection criteria for the inclusion and exclusion of relevant organisational documents. Specific documents on disability and inclusion were limited and where present in some, others were idiosyncratic to each organization and therefore were not available across each case. As an example, the Ulster GAA’s “Disability and Recreational Fact Sheet' was unique. Given the limited documents, our inclusion criteria sought any document that; referenced to relevant legislation, provided general strategic planning and capacity details, presented operational plans that focused on disability sport, or discussed specific policies on equity and inclusion. Exclusion criteria related to any document that did not discuss themes of inclusion or disability sport. The documents obtained ( $n=8$, please refer to Table 3$)$ were used as an indicator of the organization's official view on mainstreaming and were instrumental in creating the coding manual, which was used to formulate the interview questions.

\section{Please insert table 3 about here}

In our study, interview selection criteria targeted personnel with specific experience in financial control, planning, implementation and reporting of disability sport. This was justified as this group comprises staff knowledgeable on the topic and who perform the role (Marshall \& Rossman, 2016; Yin, 2018). These three specific selection criteria excluded senior officers in each organization (because of their distance from grassroots provision), and voluntary grassroots coaches (who had insufficient knowledge on the implementation of 
mainstreaming). This revealed seven possible participants across the three PSOs. During the implementation of this research we interviewed six of the seven who met these criteria. We have drawn upon a modest sample which we contend is appropriate because between the data sources they represent the organizations, documents and individuals with the most specific knowledge and experience relevant to our research question.

The interview schedule was created from literature review and document analysis. These documentary sources helped to develop a picture of the official stance of both legislative and policy directives as well as the organizations' strategic positions. Questions ranged from general conversational topics about disability sport, to more specific topics of mainstreaming and capacity (see Table 4 for an overview). One member of the research team conducted each of the interviews. Each interview lasted between 45 and 60 minutes. Once the interviews were completed they were transcribed verbatim. Once the transcript was created each researcher analysed the artefact independently. Despite the limitations of member checking (Smith \& McGannon, 2018), we offered the interviewees member checks to validate their statements and suggest any changes. Although no changes were forthcoming we felt this was ethically sound.

\section{Insert Table 4 about here}

\section{Data analysis}

To identify patterns within the data, we used a rigorous, multi-step thematic analysis to sort and analyse the data (Braun, Clarke \& Weate, 2016; Fereday \& Muir-Cochrane, 2006). Our first step was developing a coding manual to assist each researcher to manage the data. Following Fereday and Muir-Cochrane's (2006) approach, the coding manual was created $a$ priori based off the research questions, the literature review, theoretical framework and 
organizational documents. Once this was established, we followed the next step of testing the reliability of the codes against the raw data by using two documents as test pieces. As outlined by Fereday and Muir-Cochrane (2006), each document was assessed by two members of the research team and results were compared to ensure inter-rater reliability. Based on this process no modifications to the code book were required.

Once the team agreed on the creation of codes, coding the transcripts occurred (Paniccia, Colquhoun, Kirsh \& Lindsay, 2018). As coding was generated, data familiarization occurred by reading and re-reading each transcript and re-listening to the audio-recordings. Each researcher then summarized the raw data into codes, general themes and points of interest (Fereday \& Muir-Cochrane, 2006). When comparing each researcher's analysis, disagreements did occur. An example of this was often in the interpretation of a dimension of capacity (a resource being present) and an aspect of mobilizing capacity (a resource being used effectively). To enhance the trustworthiness of this process, each time a discussion ensued the codebook served as a framework for differences in interpretation (MacQueen, McLellan, Kay \& Milstein, 1998; Paniccia et al., 2018). Following data familiarization, the a priori codes drawn from the literature review guided the data retrieval process, but as this progressed, some new codes were extracted (for an example please see Table 5). Thematic saturation occurred through this process of data analysis when the a priori codes were adequately represented in the data and the extraction of new codes ceased (data saturation). The initial construction of the codebook and the comprehensive coverage of the population of managers with responsibility for this area strengthen our claims that saturation was achieved (Ando, Cousins \& Young 2014).

\section{Insert Table 5 about here}




\section{Findings}

In this section we present the findings from our multiple cases. Each case is presented separately before similarities and differences are discussed in the following section.

\section{Case 1: The Irish Football Association}

Programme objective: Increase engagement with people with disabilities

The strategic intent for developing mainstreaming was a priority guiding the IFA's current strategic plan, "Inclusive football is truly for all and must be inclusive. Everyone loves the game regardless of gender, religion, politics, race or sexual orientation. We must

continue to work to ensure all groups feel comfortable and welcome within the game" (IFA, 2013, p. 7). Their strategic plan also made specific reference to how capacity could be developed:

Professionalizing, modernizing and standardizing our systems across the domestic game will help us make the best use of existing resources, whilst growing the capacity of skills and volunteers will help us meet the demands at the grassroots level of the game. (IFA, 2013, p. 18)

However, despite the importance of capacity to their plans there was limited reference to the importance of government funding to support this work. Indeed, staff knowledge of relevant policy was ambiguous; both respondents stated that they were aware of the DMP and that it "informs our work" (Football respondent 1). Describing the DMP, the Disability Football Manager (respondent 1) summarized the policy as; "getting the main governing bodies of sport to provide opportunities for people with disabilities" and while the five features of the policy were not highlighted. There appeared to be a gap between policy and the operations at the implementation level, mimicking that which existed in the DMP and mainstreaming process, which were shortcomings of infrastructure and process capacity. 
Initially the funds were evenly used to both capital items and revenue items, but as the programme was delivered the orientation shifted towards revenue programmes. These capital purchases addressed equipment shortages for certain programmes "we used the funds to purchase power chairs, now they help us get more kids on the court" (Football respondent 2). Despite the use of funds to enhance their capacity to deliver, the manager saw non-cost items like developing relationships partners from the non-profit (for example disability charities) and the public sector (schools) as important factors for developing disability football. This was activated by "setting up [disability football] sections in mainstream clubs" (Football respondent 1). This coadoption of the responsibility for developing disability football between these organizational types aimed at relieving the workload and responsibility for improving player pathways. It was felt that shared resources were needed to assist athlete development, "A talented person in Northern Ireland with any disability, should have a pathway up to play to any reasonable level, we're trying to create these pathways so that's there's a place or anyone with a disability" (Football respondent 1).

The Disability Football Manager leveraged his networks to grow and support programmes at the performance/elite level; "we're part of an international disability football group, we share information and we play [competitions] against each other" (Football respondent 1). At the grassroots level, the manager also worked closely with external partners like the disability charity, Royal National Institute of Blind People (RNIB) in order to enhance their vision impaired/blind football programme:

We're working with just visual impairment football and we work with RNIB, they provide the expertise in visual impairment, and we provide the expertise in football. [It's a] marriage made in heaven. I have good development ideas, and I work well with partners and that's the way things develop. (Football respondent 1) 
Challenges arose when trying to mobilize this organisationally diverse network as the manager required local voluntary run clubs to partner, "clubs have the capacity across their local area to deliver for disability. They shouldn't just be concentrating on ambulant males who are going to be good footballers" (Football respondent 1). The time required to convince stakeholders that a partnership approach was the best way forward was an additional challenge as given their myriad types their motivations for involvement extended beyond the playing of disability football. Allied to this was the competencies of staff to negotiate and develop these relationships. While up-skilling human resources was another area of strategic intent, "The only way to grow our capacity to develop talent on the field is by empowering and up-skilling the passionate individuals who give up their time as coaches, referees, club secretaries, fundraisers and administrators" (IFA, 2013, p. 26), from the accounts from the programme (Deloitte, 2014) there was little evidence of these funds supporting the existing full-time staff with responsibility in this area, most funds were directed into programme delivery. Two full-time staff are responsible for the development of disability football across Northern Ireland. For both staff, their knowledge and skills in this area has accumulated over time; "we know what we're talking about, we also know what we do well and what we don't. We get through it together" (Football respondent 2).

In managing a voluntary workforce, these staff determine the necessary investment into disability football coach education. Despite additional level qualifications, a challenge for the manager was activating redundant coaches who possessed their Level 1 qualification but did not currently work, nor have the necessary skills "to adapt their practice" for disability football. To boost these skills and competencies, football offered a second level qualification:

In coach education we have two tiers in disability football, so we've a level one disability course, which is a disability awareness course and how 
you would alter your coaching techniques to incorporate people with disabilities... Then the level two, [which] is more of a practical course where you get the hands-on experience of working with various groups. (Football respondent 1)

Yet, training alone could not alleviate resource issues. A challenge faced in mobilizing human resources capacity was encouraging volunteer commitment. Sam was concerned that coaches were reluctant to work in disability football because of a perceived unease in interacting with people with disabilities. This human resource constraint was a potential barrier limiting relationships with partners; "In the clubs, the coaches may be unaware of what to do. Maybe they are scared to get involved, as they're unsure, it's the fear factor, they've no experience" (Football respondent 2).

\section{Case 2: Ulster Rugby}

Objective: To increase the number of rugby clubs providing specific sections for people with a disability from 5 to 10 by the end of the project.

Sub-Objective: To increase the number of accredited coaches working within Disability by $10 \%$ by the end of the project.

Ulster Rugby's strategic intent for disability sport was captured as one of the five values of the national organization's strategic plan - inclusivity (IRFU, 2013). This was explained as "Rugby celebrates camaraderie and teamwork which transcends gender and cultural, racial, geographic, political and religious differences" (IRFU, 2013, p. 12). Furthermore, the sport would "review and update policies and development programmes to grow and develop disability and special needs rugby" (p. 12). There was no formal strategy at the provincial level for developing disability rugby and the Rugby development manager was unaware of 
the DMP, yet actions were guided by the need "to get people out and enjoying it, enjoying the sport, in a safe environment" (Rugby Respondent). As such, funds from the programme were spent employing a professional to coordinate the disability rugby initiative. Indeed, the vast majority of funds (between 80-90\%) were divided between capital purchases (including gym equipment and motor vehicles) and staffing costs (Deloitte, 2014). At the recreational level where rugby positioned their programmes, the manager interpreted this as "about growing the game, creating opportunities for those who have never had that opportunity to be involved and fun, respect and inclusivity".

Revenue expenditure was spent on the launch of dedicated programme of tag-rugby for people with learning disabilities and the development of training courses to up-skill coaches in this area. To manage expenditure, the manager focused on developing networks and relations. The manager's ability to form relationships with organizations like DSNI and others types of organisations beyond sport was central to spread awareness of the programme, "I have consulted with Royal National Institute for the Blind (RNIB), Action on Hearing Loss, NI Deaf Youth Association, Ulster Barbarians, DSNI and I have also worked with Special Olympics [to see] what we can do there" (Rugby Respondent).

A challenge to developing networks was overcoming stakeholder assumptions about what people with learning difficulties could and could not do. The manager took these opportunities to address some wider misconceptions held about adapted sport. Changing stakeholder perceptions regarding the suitability of the sport for people with disabilities was challenging:

Whenever we go to clubs, there's still myths, it's appropriate language, there's myths about what they can and can't do, can't achieve, and we say; 'there are no boundaries, you'll be bowled over here, you will look at the person and see their ability, not their disability. (Rugby Respondent) 
The manager shared the concerns, held by managers in the upper echelons of the sport about the suitability of rugby for people with disabilities. Some at the IRFU "questioned the safety aspects" of the disability rugby. Additionally, the parents of those targeted presented another communication challenge, a group that held a major stake in the participation of many of the targeted participants;

'This is my son or daughter who has Down's Syndrome, there's no way they can play rugby!' But it's an education process to say this is noncontact, and we have found that there is a reluctance and that's why it's very much a visual work - they must see it to know it's safe, and that's a barrier. (Rugby Respondent)

From these consultations, a disability rugby advisory group was formed with representatives from stakeholders from multiple organizations, inside the sport - local clubs and PSOs and other non-sport organisations such as local governments and charities. Nevertheless, the time taken to achieve this cut into the three-year period of government funding (and the two years the manager was give to deliver the programme), thus competing with the provision of actual development work. As much as was spent on the disability and inclusion training was also spent on managing the volunteer programme to support this work. This was in response to a further human resource challenge on managing the commitment of programme volunteers, specifically in the recruitment and training of 'the right sort' of volunteers:

Mainly you find that people would come to [Rugby]. I suppose the thing is some people see it as a great thing for their CV when they're working in disability. But when they get down to the nitty-gritty - it's hard work you know? (Rugby Respondent) 
Although Ulster Rugby had no previous experience in delivering disability rugby prior to the funding, the manager and the volunteers established processes that overcome the lack of human and financial resources dedicated to disability rugby. By leveraging the advisory group network, the organization created a working group (Special Needs Tag Rugby Advisory Group) that assisted in supporting and promoting the disability rugby programme. This group coordinated the development of rugby across a series of voluntary clubs and assisted in preparing the game to be expanded to people with physical and sensory disabilities. The group also focused on process issues, such as "law adaptions, looking at medical issues and registration forms for players and the creation of a coaching schemes for disability rugby" (Rugby Respondent). This focus on processes established a foundation for the expansion of disability rugby across the province.

\section{Case 3: Ulster GAA}

Objective: To expand and enhance the Ulster Council's work in the area of disability Gaelic games across the province.

Disability sport opportunities within the Ulster GAA were supported by a provincial Strategy and Action Plan (Ulster GAA, 2009) and a National Inclusion Strategy (Gaelic Athletic Association, 2011). The Strategy and Action Plan (Ulster GAA, 2009) outlined key values. Of these values, inclusion was defined as:

"The Ulster GAA is open to everyone who subscribes to what it does and how it does it. Ulster GAA recognize however that there are historic deficits to be addressed - among them people from non-traditional Gaelic sports backgrounds, women and people with disabilities. Inclusion also means being interested in everyone who's interested in Gaelic sports, 
irrespective of their levels of ability, playing or otherwise. (Ulster GAA, 2009, p. 27)

In the above strategic document, disability sport was deemed as central to increasing and improving Gaelic sports as a whole. Indeed, it was identified as one of their 4 priority areas for growing the game; including appointing dedicated staff and upskilling the existing coaching workforce. The organization had a track record of securing government funds to support their development work: "During this decade in particular we have rightly acquired significant investment from government in order to support our development programme. This has resulted in a considerably increased capacity within the GAA in Ulster (Ulster GAA, 2009 , p. 5). Of the $40 \%$ of the programme funding from government that was designated to revenue projects such as the Disability and Special Needs [Sic.] Gaelic Programme the organisation added an additional staff member to coordinate the programme. In this case, the additional staff member was employed using funds from outside the programme. Nevertheless, of the new and existing staff, the awareness of the government's DMP was minimal, Gaelic respondent 1 commented:

I wouldn't have read it, bar the bits that we get through our own [internal] remits that we have to work on, um we just focus on them. In terms of the polices or development stuff that Sport NI have, I haven't, I wouldn't have read in depth. (Gaelic respondent 1)

The Ulster GAA Development Manager (Gaelic respondent 2) highlighted an issue with having a policy for one element of the multiple responsibilities he managed:

I'd have read through a bit of it, [disability sport] is one programme of maybe 9 or 10 that we run, the policy is fine but what I like to see is action on the ground, so we can have all the policies in the world but there's no 
action, then um then you know I think it's a waste of time. (Gaelic respondent 2)

Of the three cases, the Ulster GAA developed the smallest network to assist in the delivery of disability sport. Financial assistance from the government and at-no-cost network assistance from DSNI in tailoring their coach education programme was used to satisfy the Ulster GAA's 2009-2015 action plan “to develop strong and meaningful links with DSNI to increase participation at all levels by people with disabilities by 2012 (Ulster GAA, 2009, p. 11). DSNI's provision of disability inclusion workshops created a space: "where coaches, teachers would learn the sort of terminology, safety, barriers and other [relevant] aspects, then [we practice] how to actually incorporate someone with a disability into your session or work with different disabilities" (Gaelic respondent 2).

Even with this funding for mainstreaming disability sport, the human resources in Gaelic sports were limited to three staff, of which each had only part-time responsibility for disability sport provision. The skills and competencies needed for disability sport were developed internally, "learning on the go" (Gaelic respondent 2) and were then "passed down" (Gaelic respondent 1) amongst the staff. Personal and practical experience informed their learning "It's trial and error. You experience working in a sporting environment with children in the mainstream, and then you go and work with some disabled children" (Gaelic respondent 3). Gaelic respondent 1 outlined their experiential process:

We have a manager here who worked in the school's environment for 30something years and he has actually written disability [sport] books and resources. So, he initially trained us up, and from there a few of us attended DSNI workshops and then we worked around the province delivering inclusive games, courses and stuff like that. (Gaelic respondent 1) 
When implementing these efforts, the additional pressure placed on the existing human resource, even with the addition of the new staff member made delivery challenging. Despite the development of the DSNI's coach education workshops, concern remained over interactions when coaching; "you're always thinking twice before you open your mouth as to what you're going to say" (Gaelic respondent 3). "The words are different you know. It's hard to try and copy things into a training session, but with people with disabilities, it can be quite difficult at times" (Gaelic respondent 2). The awkwardness and inexperience of voluntary coaches maintained barriers for participants within the disability sport programmes. While the training attempted to deal with this, Gaelic respondent 1 felt the learning curve was too steep for a weekend workshop; "you need to do your own research [to gain a] decent level of knowledge on the different types of disability" (Gaelic respondent 1). Few staff and the award of the government funds created other pressures. While disability was central to the funding, it was not the PSO's only priority, this meant that staff saw it as just another area of sport development "another plate to spin for me" (Gaelic respondent 3).

\section{Discussion and Implications}

In this study, we sought to understand how Irish PSOs mobilize the capacity to mainstream disability sport. In this section, we explore the similarities and differences of the above cases to provide greater clarity on how these observations contribute to both the organizational capacity and mainstreaming disability sport literature. Following this are the implications of this study for sport managers.

Based on the analysis of these cases the receipt of dedicated funds to mainstream disability sport allowed the PSOs to mobilize their human resources. It was this human resource that then drew on their experiences to launch programmes, develop coaches and draw on contacts to establish networks that supported the mainstreaming of disability sport. 
Of these, the most important to capacity to mobilize was an organisation's relationships that would assist in the initiation of programme provision. Staff leveraged their skills, competencies and own networks to develop these links. However, all of these recent developments were underpinned by the Department of Communities' dedicated financial support for disability sport, and as such this can be assumed to mean policy support. Political support has been found previously to develop capacity at organizational levels (Marlier et al, 2015). Nevertheless, analysing the impacts between these cases, it appears that this support is overstated. The lack strategy to implement the DMP has meant that increased investment in disability sport has become equated with the whole area of disability sport being improved (Sport NI, 2012). In reality, the paucity of actionable strategies for PSOs to enhance disability sport participation in this region has resulted in what we have observed in this paper. Separate and disparate responses to the one clear objective of increasing the number of people with disabilities playing sport. In addition, nothing that was observed represented the choices that adherence to the inclusion spectrum would facilitate. Hence, it is clear that investment is increasing but as has been found previously (Hammond, 2019; Jeanes, et al, 2018) programmes are designed around performance outcomes, and not grassroots participation targets, thus reconfirming a reoccurring weakness in efforts to mainstream disability sport (Kitchin \& Howe, 2014; Sørensen \& Khars, 2006).

A number of similarities between the cases were observed. Efforts to increase the capacity of the voluntary human resources through coach education are investments that support future provision. The small staff teams were able to distribute funds, marshal volunteers, and develop and/or leverage valuable networks that in the future could build further capacity. Indeed, significant responsibility was placed upon very few staff to support this work - some who had been employed specifically for the programme, confirming again 
the importance of a committed and experienced human resource, rather than the size of one as found in previous studies (Misener \& Doherty, 2009; Sharpe, 2006; Wicker \& Breuer, 2014).

Prior to this dedicated government funding, disability sport competed for attention with other organisational development priorities. While the profile was raised, it did not appear to alter this situation - it remained one priority of many. One good result for each organisation was the network of partners who bought in with them their competencies of disability rights and awareness into sport which facilitated programme expansion. This finding extends the importance of relationships between different organizational types in nonprofit sport settings (Jones, et al., 2017, 2018; Misener \& Doherty, 2009; Misener \& Doherty, 2013; Sharpe, 2006; Svensson et al., 2018), to the disability sport context. The ongoing maintenance of these relationships could even enhance the sustainability of the work performed as these new partnerships allowed the PSOs to increase their access to participants, equipment, and advice (Misener \& Doherty, 2013). These networks were instrumental in developing each of the programmes, particularly in Ulster Rugby's case where there was no disability rugby offered by the PSO prior to the funding.

Nevertheless, the time constraints of developing networks restricted other activities, yet again confirming a common limitation found in other studies examining capacity issues (Misener \& Doherty, 2009; Sharpe, 2006). The time spent developing these networks detracted from the time available to deliver the programmes. Efforts to increase the pool of volunteer resources to overcome this was hampered by a lack of volunteer engagement. Insufficient awareness of and consideration for the rights of people with disabilities was present in each of these cases and this creates a major barrier in engaging both coaches and other sport managers (Howe, 2007; Sørensen \& Khars, 2006). Developing coach education opportunities was a possible solution to this. Yet, despite the receipt of additional training (IFA), or the initial willingness of volunteers (Ulster Rugby), respondents reported that club 
coaches lacked competence for working with people with disabilities. Because of this, we would recommend the development of a community of practice (Wenger, 1998). While the objectives of this funding were fairly rudimentary, there is a possibility of much greater learning occurring around notions of disability and sport and that multiple partners could all achieve their own objectives through involvement. As participation in such a community ebbs and flows over time, the community is responsive to change. Therefore, drawing upon and formalising partnerships from across the public, voluntary and non-sports sectors, as has been seen in parts in this study could further develop such a community. Part of the mandate of this community of practice would be to offer services for people with disabilities, which could, over time increase the competencies within sport by training volunteers and demystifying nondisabled assumptions about disability.

Concerns were observed and relate to the gaps in policy implementation and planning. There was a lack of engagement from the PSOs with mainstreaming policy possibly due to the lack of any specific targets. What awareness that did exist was either superficial (IFA, Ulster GAA) or was non-existent (Ulster Rugby). To achieve mainstreaming, five considerations needed to be met. The third consideration specifically relates to organizations consulting fully with people with disabilities. This was not done in any of the cases, hence targets around consultation could have enhanced performance. While the short timeframe of the government funds may have necessitated action over consultation, programmes offered by disability type made each programme the only option for individuals with specific impairments. Thus, while capacity was mobilized to deliver disability sport, what was offered was a limited indication of the possibilities of the inclusion spectrum (Darcy et al., 2017; Misener \& Darcy, 2014; Stevenson, 2009).

In addition to this lack of policy understanding, the lack of planning taken to prepare for and adequately scope out activities was evident in each case. This also included the 
evaluation, which was conducted by an external consultant and did little to establish how performance was monitored, nor a validation of the reported outcomes of each partner. Failure to engage in these areas meant that the performance framework only loosely articulated what success would look like, which relied heavily on vagaries and proxies for success, such as the number of training sessions delivered (Harris, 2018).

Between the cases examined in this paper we noted a number of differences in their approach to and continued support of the capacity required to achieve mainstreaming.

Differences emerged once the funding was discontinued. Gaelic sports and football sustained their programmes and incorporated them into their wider sport development offerings, while rugby discontinued their provision, including ending the contract of the manager (albeit this individual's salary was linked to programme funding which was not the case in the others). Hence, despite leveraging his own practice and experiences to develop networks to support the programme this was seemingly undermined by a lack of higher managerial support and insufficient financial capital - contrasting sharply with the claims made at the National level about the importance of inclusion within the sport. These findings further support findings from research on the mainstreaming of disability sport (Kitchin \& Howe, 2014; Sørensen \& Khars, 2006) hinting that decisions to include disability sport are usually exogenous and once external support ends, so too does provision.

From these findings, we offer some implications for sport managers. Peak sports agencies like Sport Councils and relevant government departments should articulate policy more effectively to clarify direction on social integration efforts. While the multiple cases revealed much output, they launched their efforts with little pre-planning - performed in absence of concrete suggestions in the form of a strategy from the DMP. Rather than offering the funds to be spent at the behest of each PSO, our recommendations mimic those of Casey et al., (2012) in that specific funds should be allocated to develop partnerships and, 
as mentioned above, communities of practice that would then ensure appropriate expertise form individuals and organisations outside of sport that could assist in attracting funds in order to facilitate sustainable and engaging provision.

Greater efforts are required to engage people with disabilities in sport programming. The programmes in these cases were developed without their input and as such, the lack of choice in the provision delivered may have been identified earlier and a broader set of provisions could have been created. What exists risk being seen as 'paternalistic provision' (Sharpe, 2006, p. 399) whereby users are merely passive recipients of the services devised by the (mostly nondisabled) sport development profession. Finally, in order to more effectively mobilize human capacity, long term financial capacity should be dedicated to the ongoing training of all organizational stakeholders (senior managers, coaches and parents) in disability awareness and inclusivity (from across the programme less than $5 \%$ of the funds were spent on this type of training, and none on existing staff within the IFA, Ulster GAA, or Ulster Rugby). The instilling in each stakeholder a sense of social responsibility that their sport is accessible and designed for the needs of a myriad of potential users could arise through these forms of training.

\section{Conclusion}

This article has presented a multiple case study analysis of how Irish PSOs mobilized their capacity to support the mainstreaming of disability sport. By seeking to understand how this was done, this paper's findings contribute to contextual studies in both the general organizational capacity and management of disability sport literatures. Each case presented above clearly shows that financial capacity was available because of dedicated funds to implement a mainstreaming policy, and this resource was then mobilized by a small yet committed staff who drew on their experiences and contacts to develop the coaching 
workforce and appropriate networks. Our findings reconfirm the importance human resources in the non-profit sport context (Misener \& Doherty, 2009; Sharpe, 2006; Wicker \& Breuer, 2014) while reinforcing too the importance of available finance. The mobilization of these funds, the commitment of the human resources and the networks formed all enabled mainstreaming to occur. However, rather than policy intent being understood and then acted upon, the lack of a strategic plan for disability sport participation meant that mobilization only occurred once funds were provided. This resulted in a flurry of activity prioritising performance, thus needing a more strategic approach in the future. The resultant programmes offered people with disabilities limited choices and could have been made more inclusive.

We contend that an appropriate needs assessment, prior-planning and actual engagement with users in programmes design is needed. Without these, disability sport provision in this research was offered to specific disability types only, which effectively limited the full range of choices that could be made available to the participants.

\section{Limitations and future directions}

It is also understood that typically case studies lack generalizability (Millar \& Doherty, 2018; Misener \& Doherty, 2009), however we concur with Shaw (2016) in suggesting that there is a renewed focus on enhancing the case for qualitative research by moving away from concepts and ideas that are inherited from more positivistic epistemologies. We seek to provide the reader with the claim that our results assist in the conceptualization of how organizational capacity is mobilized to cater for non-traditional participants in mainstream sports organizations. To this end, we present three points that could increase these claims of transferability. First, Doherty, Misener and Cuskelly (2014) suggested that the study of organizational capacity requires different perspectives from many contexts to develop a more comprehensive understanding of how capacity facilitates or limits a non-profit's mission. 
Second, the implications presented in the previous section are relevant for practitioners seeking to integrate marginalized groups into sport in many contexts. Third, we present multiple organizations who each sought to mobilize capacity in order to achieve mainstreaming, with the differences between them each demonstrating varying levels of success. While we are careful to not over-reach and suggest these findings should apply across contexts, we believe these findings to be useful in the comparison of future cases, ultimately revealing our work's level of comparability.

Opportunities for further study are available. Research needs to be undertaken into understanding the quality of programming from a participant's perspective. This could be done with a view to gaining recommendations on areas of optimum impact that would enable the organizations to refocus their scarce resources to other areas as needed. Further research could also explore the role of government and peak agencies in ensuring that policy enactments are implemented in the programmes they fund and how needs assessments are performed within the organizations they fund. 


\section{References}

Adams, A. (2014). Social capital, network governance and the strategic delivery of grassroots sport in England. International Review of the Sociology of Sport, 49(5), 550-574.

Allison, M. (2001). Sports clubs in Scotland. Edinburgh, Scotland: Sport Scotland.

Ando, H., Cousins, R., and Young, Y. (2014). Achieving saturation in thematic analysis: development and refinement of a codebook. Comprehensive Psychology, 3, 4.

Balduck, A.L., Lucidarme, S., Marlier, M., and Willem, A. (2015). Organizational capacity and organizational ambition in nonprofit and voluntary sports clubs. VOLUNTAS: International Journal of Voluntary and Nonprofit Organizations, 26, 2023-2043.

Berry, J. W. (1997). Immigration, acculturation and adaption. Applied Psychology,46, 5-34.

Braun, V., Clarke, V., and Weate, P. (2016). Using thematic analysis in sport and exercise research. In B. Smith and A.C. Sparkes (Eds). Routledge handbook of qualitative research in sport and exercise (pp. 191-205). Oxon: Routledge.

Brittain, I. (2004). Perceptions of disability and their impact upon Involvement in sport for people with disabilities at all levels. Journal for Sport and Social Issues, 28(4), 429-452.

Casey, M.M., Payne, W.R., and Eime, R.M. (2009a). Building the health promotion capacity of sport and recreation organisations: A case study of Regional Sports Assemblies. Managing Leisure, 14(2), 112-124.

Casey, M.M., Payne, W.R., and Eime, R.M. (2009b). Partnership and capacity-building strategies in community sports and recreation programs. Managing Leisure, $14(3), 167-176$. 
Casey, M. M., Payne, W. R., and Eime, R.M. (2012). Organisational readiness and capacity building strategies of sporting organisations to promote health. Sport Management Review, 15(1), 109-124.

Collins, M. and Kay, T. (2003). Sport and social exclusion. Oxon: Routledge

Crawford, J. L., and Stodolska, M. (2009). Constraints experienced by elite athletes with disabilities in Kenya, with implications for the development of a new hierarchical model of constraints at the societal level. Journal of Leisure Research, 40(1), 128-156.

Darcy, S., Lock, D. and Taylor, T. (2017). Enabling inclusive sport participation: Effects of disability and support needs on constraints to sport participation. Leisure Sciences, 39(1), 20-41.

Deloitte. (2014). A sporting chance: evaluation of promoting equality, tackling poverty, and social exclusion through sport. Belfast: Deloitte.

Dey, P., and Teasdale, S. (2016). The tactical mimicry of social enterprise strategies: Acting 'as if' in the everyday life of third sector organizations. Organization, 23(4), 485-504.

Doherty, A., Misener, K., and Cuskelly, G. (2014). Toward a multidimensional framework of capacity in community sport clubs. Nonprofit and Voluntary Sector Quarterly, $43(2 \mathrm{~S}), 124 \mathrm{~S}-142 \mathrm{~S}$.

Eisinger, P. (2002). Organizational capacity and organizational effectiveness among street level food assistance programs. Nonprofit and Voluntary Sector Quarterly, 31, $115-130$.

Fereday, J., and Muir-Cochrane, E. (2006). Demonstrating rigor using thematic analysis: A hybrid approach of inductive and deductive coding and theme development. International Journal of Qualitative Methods, 5(1), 80-92. 
Fitzgerald, H. (2012). 'Drawing' on disabled students' experiences of physical education and stakeholder responses. Sport, Education and Society, 17(4), 443-462.

French, D., and Hainsworth, J. (2001). 'There Aren't any Buses and the Swimming Pool is Always Cold!': Obstacles and Opportunities in the Provision of Sport for Disabled People. Managing Leisure, 6, 35-49.

Gaelic Athletic Association. (2011) Equity and inclusion policy. Gaelic Athletic Association. Dublin.

Germann, K., and Wilson, D. (2004). Organizational capacity for community development in regional health authorities: A conceptual model. Health Promotion International, 19, 289-298.

Griginov, V., Peshin, N. and Belousov, L. (2017). Leveraging mega events for capacity building in voluntary sport organisations. VOLUNTAS: International Journal of Voluntary and Nonprofit Organizations, 28(5), 2081-2102.

Hall, M., Andrukow, A., Barr, C., Brock, K., de Wit, M., Embuldeniya, D., et al. (2003). The capacity to serve: A qualitative study of the challenges facing Canada's nonprofit and voluntary organizations. Toronto, ON: Canadian Centre for Philanthropy.

Hammond, A. (2019). The mainstreaming of disability swimming in Australia, 1990-2016. Sporting Traditions, 36(1), 43-62.

Hammond, A., Penney, D., and Jeanes, R. (2019). Sport coaches as policy actors: an investigation of the interpretation and enactment of disability and inclusion policy in swimming in Victoria Australia. Sport, Education and Society, in press at https://www.tandfonline.com/doi/full/10.1080/13573322.2019.1628013

Harris, K. (2018). Building sport for development practitioners' capacity for undertaking monitoring and evaluation - reflections on a training programme building 
capacity in realist evaluation. International Journal of Sport Policy and Politics, 10(4), 795-814.

Harris, S. and Houlihan, B. (2015). Competition or coalition? Evaluating the attitudes of ,national governing bodies of sport and county sport partnerships towards school sport partnerships. International Journal of Sport Policy and Politics, 7(2), 151171.

Harris, S., and Houlihan, B. (2016). Implementing the community sport legacy: the limits of partnerships, contracts and performance management. European Sport Management Quarterly, 16, 433-458.

Haudenhuyse, R. (2017). Introduction to the issue "sport for social inclusion: questioning policy, practice and research. Social Inclusion, 5(2), 85-90.

Howe, P. D. (2007). Integration of Paralympic Athletes into athletics Canada. International Journal of Canadian Studies/Revue international d'etudes Candiennes, 35, 133150.

Hums, M.A., Moorman, A.M., and Wolff, E.A. (2003). The inclusion of the Paralympics in the Olympic and amateur sports act: Legal and policy implications for integration of athletes with disabilities into the United States Olympic Committee and national governing bodies Journal of Sport and Social Issues 27(3), 261-275.

Irish Football Association (2013). 'We're not Brazil... We're Northern Ireland.' The Irish Football Association Strategic Plan, 2013-2018. Accessed on $14^{\text {th }}$ August, 2019 at http://www.irishfa.com/media/3975/ifa_strategy_final_proof_19_nov_2013.pdf

Jeanes. R., Spaaij, R., Magee, J., Farquharson, K., Gorman, S., and Lusher, D. (2017). 'Yes we are inclusive': Examining provision for young people with disabilities in community sport clubs. Sport Management Review, 21(1), 38-50. 
Jones, D. B. (2003). "Denied from a lot of places" barriers to participation in community recreation programs: Perspectives of parents. Leisure/Loisr, 28(1-2), 49-69.

Jones, G., Edwards, M.B., Bocarro, J.N., Bunds, K.S., and Smith, J.W. (2017). Collaborative advantages: the role of interorganizational partnerships for youth sport nonprofit organizations. Journal of Sport Management, 31(2), 148-160.

Jones, G., Edwards, M.B., Bocarro, J.N., Bunds, K.S., and Smith, J.W. (2018). A structural perspective of cross-sector partnerships involving youth sport nonprofit organizations. European Sport Management Quarterly, 18(2), 133-155.

Kitchin, P. J., and Howe, D. (2014). The mainstreaming of disability cricket in England and Wales: integration 'one game' at a time. Sport Management Review, 17(1), 65-77.

Kitchin, P.J., and Crossin, A. (2018). Understanding which dimensions of organisational capacity support the vertical integration of disability football clubs. Managing Sport and Leisure, 23(1-2), 28-47.

Le Clair, J. M. (2011). Global organizational change in sport and the shifting meaning of disability. Sport in Society, 14(9), 1072-1093.

Liston, K., Gregg, R., and Lowther, L. (2013). Elite sports policy and coaching at the coalface. International Journal of Sport Policy and Politics, (5)3, 341-362.

Mackintosh, C., Darko, N., Rutherford Z., and Wilkins, H. (2015). A qualitative study on the impact of the London 2012 Olympics on families in the East Midlands of England: lessons for sports development policy and practice. Sport, Education and Society, 20, 1065-1087.

MacQueen, K. M., McLellan, E., Kay, K., and Milstein, B. (1998). Codebook development for team-based qualitative analysis. Cultural Anthropology Methods, 10, 31-36.

Marlier, M. Lucidarme, S., Cardon, G, De Bourdeaudhuij, I., Babiak, K., and Willem, A. (2015). Capacity building through cross-sector partnerships: a multiple case study 
of a sport program in disadvantaged communities in Belgium. BMC Public Health, 15, 1306.

Marshall, C., and Rossman, G.B. (2016). Designing qualitative research (6 ${ }^{\text {th }}$ ed.). Singapore: Sage.

Malterud, K., Siersma, V., and Guassora, A. (2015). Sample size in qualitative interview studies: Guided by information power. Qualitative Health Research, 26, 17531760.

McGrath, R. (2009). A discourse analysis of Australian local government recreation and sport plans provision for people with disabilities. Public Management Review, 11(4), $477-497$.

Millar, P., and Doherty, A. (2016). Capacity building in nonprofit sport organizations: Development of a process model. Sport Management Review, 19, 365-377. Millar, P., and Doherty, A. (2018). "You can't just start and expect it to work”: an investigation of strategic capacity building in community sports organizations. Journal of Sport Management, 32(4), 348-361.

Misener, L., and Darcy, S. (2014). Managing disability sport: From athletes with disabilities to inclusive organisational perspectives. Sport Management Review, 17(1), 1-7.

Misener, K., and Doherty, A. (2009). A case study of organizational capacity in community sport. Journal of Sport Management, 23, 457-482.

Misener, K., and Doherty, A. (2013). Understanding capacity through the processes and outcomes of interorganizational relationships in nonprofit community sport organizations. Sport Management Review, 16(2), 135-147.

Irish Rugby Football Union. (2013). From grassroots to international success; one island, one passion, one goal. Strategic plan for Irish rugby 2013-2017. Dublin: IRFU. 
Paniccia, A. Colquhoun, H., Kirsh, B., and Lindsay, S. (2018). Youth and young adults with acquired brain injury transition towards work-related roles: a qualitative study, Disability and Rehabilitation, 41(11), 1331-1342.

Paramio-Salcines, J. L., Grady, J., and Downs, P. (2014) Growing the football game: the increasing economic and social relevance of older fans and those with disabilities in the European Football Industry. Soccer in Society, 15(6), 864-882.

Paramio-Salcines, J. L., and Kitchin P. J. (2013). Institutional perspectives on the implementation of disability legislation and service for Spectators with Disabilities in European professional football. Sport Management Review, 16, 337-348.

Prior, L. (2003). Using documents in social research. London: Sage.

Rosso, E. G. F., and McGrath, R. (2017) Community engagement and sport? Building capacity to increase opportunities for community-based sport and physical activity. Annals of Leisure Research, 20(3), 349-367.

Sharpe, E. K. (2006). Resources at the grassroots of recreation: Organizational capacity and quality of experience in a community sport organization. Leisure Sciences, 28, $386-401$.

Shaw, S. (2016). Importance of theory in qualitative enquiry. In G.B. Cunningham, J.S. Fink, and A. Doherty (Eds.). Routledge handbook of theory in sport management (pp. 21-29). London: Routledge.

Skille, E. A. (2008). Sport policy implementation. In G. Cunningham, J.S. Fink, and A. Doherty (Eds.) Routledge Handbook of Theory in Sport Management (pp. 8290). Oxon: Routledge. 
Spaaij, R., Farquharson, K., Magee, J., Jeanes, R., Lusher, D., and Gorman, S. (2014). A fair game for all? How community sport clubs in Australia deal with diversity. Journal of Sport and Social Issues, 38(4), 346-365.

Sport NI. (2011). An impact review of Sport Northern Ireland's disability mainstreaming policy. Belfast: Sport Northern Ireland.

Sport NI. (2012). Sport and physical activity survey. Belfast: Sport Northern Ireland.

Sørensen, M., and Kahrs, N. (2006). Integration of disability sport in the Norwegian sport organizations: Lessons learned. Adapted Physical Activity Quarterly, 23, 184202.

Sotiriadou, P., and Wicker, P. (2014). Examining the participation patterns of an ageing population with disabilities in Australia. Sport Management Review, 17(1), 3548.

Stake, R.E. (2006). Multiple case study analysis. New York, NY: Guilford Press.

Stenling, C. (2013). The introduction of drive-in sport in community sport organizations as an example of organizational non-change. Journal of Sport Management, 27, 497509.

Stevenson, P. (2009). The pedagogy of inclusive youth sport: working towards real solutions; in H. Fitzgerald (Ed.), Disability and youth sport (pp. 119-131). Oxon: Routledge.

Sugden, J.P. (1991). Belfast United: Encouraging cross-community relations through sport in Northern Ireland. Journal of Sport and Social Issues, 15(1), 59-80.

Svensson, P.G., Hancock, M.G., and Hums, M.A. (2017). Elements of capacity in youth development nonprofits: An exploratory study of urban sport for development and peace organizations. VOLUNTAS: International Journal of Voluntary and Nonprofit Organizations, 28, 2053-2080. 
Svensson, P.G., and Hambrick, M.E. (2018). Exploring how external stakeholders shape social innovation in sport for development and peace. Sport Management Review, 22(4), 540-552.

Svensson, P.G., Andersson, F.O., and Faulk, L. (2018). A quantitative assessment of organizational capacity and organizational life stages in sport for development and peace. Journal of Sport Management, 32(3), 295-313.

Swierzy, P., Wicker, P., and Breuer, C. (2018). The impact of organisational capacity on voluntary engagement in sport clubs: A multi-level analysis. Sport Management Review, 21(3), 307-320.

Thomas, N., and Smith, A. (2009). Disability, sport and society: an introduction. Oxon: Routledge.

Thomas, M. M., Hodge, W., and Smith, B. J. (2009). Building capacity in local government for integrated planning to increase physical activity: evaluation of the VicHealth MetroACTIVE program. Health Promotion International, 24(4), 353-362.

Thomson, A., Darcy, S., and Pearce, S. (2010). Ganma theory and third-sector sportdevelopment programmes for Aboriginal and Torres Strait Islander youth: implications for sports management. Sport Management Review, 13(4), 313-330.

Ulster GAA. (2009). Teaghlaigh agus Pobail: An Fabraic de CLG / Family and Community: The Fabric of the GAA. Ulster GAA: Armagh.

Ulster GAA (2011). Annual Report to Convention. Accessed on $14^{\text {th }}$ August 2019 at http://ulster.gaa.ie/wp-content/uploads/council/annual-reports/TuarascailBhliant\%C3\%BAil-2011.pdf

Ulster GAA (2012). Annual Report to Convention. Accessed on $14^{\text {th }}$ August 2019 at http://ulster.gaa.ie/wp-content/uploads/council/annual-reports/TuarascailBhliant\%C3\%BAil-2012.pdf 
Wahyuni, D. (2012). The research design maze: understanding paradigms, cases, methods and methodologies. Journal of Applied Management Accounting Research, 10(1), 6980.

Wenger, E. (1998). Communities of practice: learning, meaning and identity. Cambridge: Cambridge University Press.

Wicker, P., and Breuer, C. (2012). Scarcity of resources in German non-profit sport clubs. Sport Management Review, 14(2), 188-201.

Wicker, P., and Breuer, C. (2013). Understanding the importance of organizational resources to explain organizational problems: Evidence from non-profit sport clubs in Germany. VOLUNTAS: International Journal of Voluntary and Nonprofit Organizations, 24(2), 461-484.

Wicker, P., and Breuer, C. (2014). Exploring the organizational capacity and organizational problems of disability sport clubs in Germany using matched pairs analysis. Sport Management Review, 17(1), 23-34.

Wright, T., and Cunningham, G. (2017). Disability status, stereotype content, and employment opportunities in sport and fitness organizations. Sport, Business and Management: An International Journal, 7(4), 393-403.

Yin, R.K. (2018). Case study research and applications: Design and methods $\left(6^{\text {th }} \mathrm{ed}\right)$. Thousand Oaks, CA: Sage. 
Table 1

Sport and Physical Activity Survey 2010 KPI results

\begin{tabular}{|c|c|c|c|c|}
\hline KPI & Item & Description & $\begin{array}{l}\text { General } \\
\text { Population }\end{array}$ & $\begin{array}{l}\text { People } \\
\text { with } \\
\text { disabiliti } \\
\quad \text { es }\end{array}$ \\
\hline KPI 1 & $\begin{array}{l}\text { Physical } \\
\text { activity }\end{array}$ & $\begin{array}{l}\text { The proportion of adults participating in at least } \\
30 \text { minutes of at least moderate intensity activities } \\
\text { per day (which can be made up of bouts of at least } \\
10 \text { minutes) on at least five days in the last seven } \\
\text { days. This definition is derived from the Chief } \\
\text { Medical Officer's recommendation with regard to } \\
\text { physical activity. }\end{array}$ & $35 \%$ & $23 \%$ \\
\hline KPI 2 & $\begin{array}{l}\text { Sport } \\
\text { participation }\end{array}$ & $\begin{array}{l}\text { The proportion of adults participating in sporting } \\
\text { activities of at least moderate intensity in the last } \\
\text { seven days (for at least } 30 \text { minutes in duration). }\end{array}$ & $37 \%$ & $19 \%$ \\
\hline KPI 3 & $\begin{array}{l}\text { Club } \\
\text { membership }\end{array}$ & $\begin{array}{l}\text { The proportion of adults having been a member of } \\
\text { at least one club in which they can participate in } \\
\text { sport or physical activity in the last four weeks. }\end{array}$ & $23 \%$ & $13 \%$ \\
\hline KPI 4 & Competitions & $\begin{array}{l}\text { The proportion of sports participants having taken } \\
\text { part in at least one organized sporting competition } \\
\text { in the last } 12 \text { months. }\end{array}$ & $22 \%$ & $12 \%$ \\
\hline KPI 5 & Coaching & $\begin{array}{l}\text { The proportion of sports participants having } \\
\text { received coaching in the last } 12 \text { months. }\end{array}$ & $18 \%$ & $10 \%$ \\
\hline KPI 6 & Volunteering & $\begin{array}{l}\text { The proportion of adults having carried out any } \\
\text { sports voluntary work without receiving any } \\
\text { payment except to cover expenses in the last } 12 \\
\text { months. This includes, for example, helping to run } \\
\text { an event, raising money, providing transport, } \\
\text { coaching or mentoring but not the time spent } \\
\text { solely supporting family members. }\end{array}$ & $9 \%$ & $7 \%$ \\
\hline KPI 7 & $\begin{array}{l}\text { Live } \\
\text { sporting } \\
\text { events }\end{array}$ & $\begin{array}{l}\text { The proportion of adults having attended at least } \\
\text { one live sporting event in Northern Ireland in the } \\
\text { last } 12 \text { months. }\end{array}$ & $37 \%$ & $24 \%$ \\
\hline KPI 8 & $\begin{array}{l}\text { Satisfaction } \\
\text { with sports } \\
\text { provision }\end{array}$ & $\begin{array}{l}\text { The proportion of adults satisfied with sports } \\
\text { provision in their local area. }\end{array}$ & $62 \%$ & $53 \%$ \\
\hline
\end{tabular}

Source: Sport NI (2012) 
Table 2

Case organizations and their governance of disability sport

\begin{tabular}{|c|c|c|c|}
\hline Case & $\begin{array}{l}1 \text { Irish Football } \\
\text { Association }\end{array}$ & 2 Ulster Rugby & 3 Ulster GAA \\
\hline $\begin{array}{l}\text { Governance } \\
\text { Structures }\end{array}$ & $\begin{array}{l}\text { Operates as } \\
\text { National Governing } \\
\text { Body. }\end{array}$ & $\begin{array}{l}\text { Reports to National } \\
\text { Governing Body in } \\
\text { Dublin. } \\
\text { Operates as both } \\
\text { Professional Club } \\
\text { and Provincial } \\
\text { Development } \\
\text { Organization }\end{array}$ & $\begin{array}{l}\text { Reports to National } \\
\text { Governing Body in } \\
\text { Dublin. } \\
\text { Provincial } \\
\text { Development } \\
\text { Organization. }\end{array}$ \\
\hline Head office & Belfast & Belfast & Armagh \\
\hline Scope of operations & $\begin{array}{l}\text { Northern Ireland }-6 \\
\text { counties }\end{array}$ & $\begin{array}{l}\text { Ulster region }-9 \\
\text { counties }\end{array}$ & $\begin{array}{l}\text { Ulster region - } 9 \\
\text { counties }\end{array}$ \\
\hline Number of staff & 100 & 70 & 60 \\
\hline $\begin{array}{l}\text { Number of staff } \\
\text { dedicated to } \\
\text { disability sport } \\
\text { (2015) }\end{array}$ & $\begin{array}{l}2 \text { FT (permanent } \\
\text { contracts) }\end{array}$ & $\begin{array}{l}0 \mathrm{FT} \\
1 \mathrm{PT} \text { (temporary } \\
\text { contract) }\end{array}$ & $\begin{array}{l}0 \mathrm{FT} \\
3 \text { PT (permanent } \\
\text { contracts) }\end{array}$ \\
\hline $\begin{array}{l}\text { Level of decision- } \\
\text { making control of } \\
\text { disability sport }\end{array}$ & $\begin{array}{l}\text { Development } \\
\text { Department - } \\
\text { Middle manager }\end{array}$ & $\begin{array}{l}\text { Development } \\
\text { Department - Junior } \\
\text { Officer }\end{array}$ & $\begin{array}{l}\text { Inclusion } \\
\text { Department - } \\
\text { Middle manager }\end{array}$ \\
\hline $\begin{array}{l}\text { Pre-existing } \\
\text { Disability sport } \\
\text { development focus }\end{array}$ & $\begin{array}{l}\text { Grassroots and Elite } \\
\text { Schools and } \\
\text { communities } \\
\text { programme } \\
\text { Disability Football } \\
\text { Development } \\
\text { Programme }\end{array}$ & $\begin{array}{l}\text { Grassroots } \\
\text { Schools and } \\
\text { communities } \\
\text { programme } \\
\text { International Tag } \\
\text { Rugby Festival for } \\
\text { People with } \\
\text { Disabilities }\end{array}$ & $\begin{array}{l}\text { Grassroots } \\
\text { Schools and } \\
\text { communities } \\
\text { programme } \\
\text { Disability Gaelic } \\
\text { Games Programme: }\end{array}$ \\
\hline $\begin{array}{l}\text { Model of } \\
\text { development }\end{array}$ & Club and NGB & Club & Regional Hub \\
\hline
\end{tabular}

Source: Authors 
Table 3

Summary of data sources used in case analysis

\begin{tabular}{|c|c|c|c|}
\hline & Case 1 & Case 2 & Case 3 \\
\hline \multirow[t]{2}{*}{$\begin{array}{l}\text { Semi-structured } \\
\text { interviews }\end{array}$} & $\begin{array}{l}2 \text { interviews ( } 45 \text { and } \\
55 \text { min) }\end{array}$ & 1 interview $(60 \mathrm{~min})$ & $\begin{array}{l}3 \text { interviews (45-60 } \\
\text { min) }\end{array}$ \\
\hline & $\begin{array}{l}\text { Follow-up } \\
\text { conversations and } \\
\text { emails }\end{array}$ & $\begin{array}{l}\text { Follow-up } \\
\text { conversations and } \\
\text { emails }\end{array}$ & $\begin{array}{l}\text { Follow-up } \\
\text { conversations and } \\
\text { emails }\end{array}$ \\
\hline \multirow[t]{3}{*}{ Documents analysed } & $\begin{array}{l}\text { Organizational } \\
\text { strategy "We're not } \\
\text { Brazil, we're } \\
\text { Northern Ireland" } \\
\text { 2013-2018 }\end{array}$ & $\begin{array}{l}\text { Organizational } \\
\text { strategy "From } \\
\text { Grassroots to } \\
\text { International } \\
\text { Success; One Island, } \\
\text { One Passion, One } \\
\text { Goal" 2013-2017 }\end{array}$ & $\begin{array}{l}\text { The GAA (2011) } \\
\text { "Equity and } \\
\text { Inclusion Policy" } \\
\text { Organizational } \\
\text { strategy - } \\
\text { "Teaghlaigh agus } \\
\text { Pobail: An Fabraic } \\
\text { de CLG" 2009-2015 }\end{array}$ \\
\hline & $\begin{array}{l}\text { Disability sport } \\
\text { development } \\
\text { strategy }\end{array}$ & & $\begin{array}{l}\text { Disability and } \\
\text { Recreational Fact } \\
\text { Sheet }\end{array}$ \\
\hline & $\begin{array}{l}\text { Equity and inclusion } \\
\text { policy }\end{array}$ & & $\begin{array}{l}\text { Ulster Council } \\
\text { Disability and } \\
\text { Special Needs } \\
\text { Strategy 2006-2008 }\end{array}$ \\
\hline $\begin{array}{l}\text { Additional } \\
\text { documents }\end{array}$ & \multicolumn{3}{|c|}{$\begin{array}{l}\text { Deloitte (2014) A Sporting Chance. Evaluation of Promoting } \\
\text { Equality, Tackling Poverty and Social Exclusion through Sport: } \\
\text { Final Report }\end{array}$} \\
\hline
\end{tabular}

Source: Authors 
Table 4

Examples of interview questions

Interview questions

- In what areas did you feel your organization was deficient in prior to the funding?

- What specific challenges have you encountered now that extra resources have been received?

- Could you identify one factor that would increase your capacity to increase the number of participants taking up these programmes?

- How would the development of this element impact on other organizational factors that assist mainstreaming?

Source: Authors 
Table 5

Examples of a priori and extracted codes

\begin{tabular}{|c|c|}
\hline Type of code & Details \\
\hline A priori code label & Human resources capacity \\
\hline Definition & $\begin{array}{l}\text { The ability to deploy human capital (i.e., } \\
\text { paid staff, volunteers) within the } \\
\text { organization, and includes the } \\
\text { competencies, knowledge, attitudes, } \\
\text { motivation, and behaviours of individuals in } \\
\text { the organization. (Misener \& Doherty, } \\
2009, \text { p. } 462 \text { ). }\end{array}$ \\
\hline Description & $\begin{array}{l}\text { The human capacity to understand disability } \\
\text { and/or disability sport, the aims and process } \\
\text { of mainstreaming, and approaches and } \\
\text { methods for delivering opportunities. }\end{array}$ \\
\hline Example from transcripts & $\begin{array}{l}\text { Back then there was only } 3 \text { staff, a coach } \\
\text { educator, a high performance director, and a } \\
\text { sport development manager, so in terms of } \\
\text { the organization we didn't really have the } \\
\text { staff structure to drive [disability sport], and } \\
\text { it's only when we started to get the specific } \\
\text { officers in place on a regional basis, that } \\
\text { they all got a special project if you want, } \\
\text { one for Clubmark, another for disability } \\
\text { [sport], and someone else for school sport. } \\
\text { (Gaelic respondent 1, GAA) }\end{array}$ \\
\hline
\end{tabular}

Extracted code label

Awkwardness

Definition

The clumsiness and uncertainty of nondisabled sport managers and coaches in interacting and communicating with a person with a disability.

Contextual description Uncertainty in communicating and interacting with people with disabilities and an insufficient understanding of how to modify sports programs to cater for a wider array of abilities.

Example from transcripts

I think that's a challenge for all the coaches, knowing the right language and not offending people, and for those that are in and at it on a daily basis it's become second nature but for some of the rest of us who are not directly engaging then that's you're always thinking twice before you open your 
mouth as to what you're going to say

(Gaelic Respondent 2, GAA)

Source: Authors and cited sources 